\title{
Implementation and Management of Life Cycle Approaches in Business- Challenges, Opportunities, Business Learnings and Best Practice
}

\author{
Lena Landström and Sara Palander
}

\begin{abstract}
This paper presents a summary of the session "Implementation and management of life cycle approaches in business-challenges, opportunities, business learnings and best practice". In the session, the audience got the opportunity to listen to examples from industry and ways to include life cycle approaches in their business decision making processes. The audience also attended presentations where learnings from the environmental footprint process were discussed. The conclusions from the presentations and the final panel discussion can be summarized in some key messages. To succeed we need to go together and that is why harmonization of e.g. methods and regulations are important. As a basis when developing the way forward it was concluded that the life cycle approach is an important tool.
\end{abstract}

\section{Introduction}

During the latest decades, companies have implemented life cycle assessment (LCA) into business management processes, e.g. in strategy, investment, procurement, and marketing, with the objective to increase the environmental performance of their products and services. In the latest update of the standard ISO 14001:2015 (environmental management systems, EMS), companies shall use a life cycle perspective to fulfil the requirements when for instance identifying the most important and relevant environmental impacts [1]. Also, the Product and

\footnotetext{
L. Landström

Vattenfall, Gothenburg, Sweden

L. Landström $\cdot$ S. Palander $(\square)$

Chalmers University of Technology, Swedish Life Cycle Center,

41296 Gothenburg, Sweden

e-mail: sara.palander@chalmers.se

S. Palander

Chalmers University of Technology, Centre for Environment

and Sustainability, 41296 Gothenburg, Sweden

(C) The Author(s) 2018

E. Benetto et al. (eds.), Designing Sustainable Technologies,

Products and Policies, https://doi.org/10.1007/978-3-319-66981-6_18
} 
Organisation Environmental Footprint process of the European Commission will affect the international market and business to apply the life cycle approach in decision making and communication [2]. So how does industry embed life cycle approaches into their business? What is best practice? How are ISO 14001:2015 and the Product/Organisation Environmental footprint process (respectively PEF and $\mathrm{OEF}$ ) being used and can they support the work of improving the environmental performance of products, services and organizations?

The session invited industries to present different ways to implement the life cycle perspective into their environmental management systems, learnings and best practices. The session also invited presenters to take up from results and learnings from the European PEF/OEF process. What is the next step for businesses, policy-makers and the life cycle management community in order to create a more sustainable industry and communicate results to customers, citizens and other stakeholders? What actions have been seen and will be seen? What are the opportunities and challenges? The session attracted many abstracts with different perspectives and the presenters were selected to reflect those perspectives with the hopes of a fruitful panel discussion at the end of the session.

\section{Main Messages from the Presentations}

Three oral presentations were selected to describe different ways of how life cycle approaches and life cycle management were incorporated into business strategies. At Procter \& Gamble, the OEF has been used to understand the corporate hot spots and identify sustainability actions based on these, quantify progress over time and effectively report to external programs such as CDP [3].

Aptar Italia's roadmap towards sustainability was presented to give an insight in the company's use of LCA as a basis for their business. The organization's most important strategic principle is the customers' awareness of the value of sustainability [4].

AkzoNobel has used monetization of externalities (expressing consequences of an economic activity experienced by unrelated third party in monetary/financial terms) as an approach to integrate life cycle management in decision making. The methods behind the "3D profit and loss account" were described and also the methods behind the economic, environmental and social capital for both positive and negative externalities, e.g. the Environmental Priority Strategies (EPS) [5].

The last two presentations were selected to give insights and perspectives on the environmental footprint process from the European Commission. The OEF process was discussed by one of the OEF pilots in the retail sector and from a communication effectiveness perspective. The pilot study shows both a potential and a value of OEF as it helps retailers to assess and improve their product portfolio and to make sure their sustainability strategy targets major issues first [6].

The communication effectiveness was studied through how human brains interpret environmental information on products and how to use this information in 
communication of life cycle based environmental labelling. The key message from the research group behind the presentation is education of consumers in all levels of the society [7].

\section{Discussion on Messages and Outcomes}

After their talk, the presenters were invited to be part of a panel discussion to raise the perspective of the individual company to a society level.

They were first invited to discuss the actions needed in order to make progress towards a more sustainable industry, what actions are needed.

Need for harmonization and collaboration were agreed on among the participants in the panel. According to Mr. Van Hoof, "International harmonization is a key word to drive sustainability actions". Mr. Van Hoof and Mr. Van Hemelryck also discussed the importance of communicating products' environmental impact and understand customers' needs and interest were also discussed. Mr. Sonnen added the perspectives on financial rewarding systems to the table, and Mrs. Lewandowska highlighted the importance of education and to educate employees, business partners, customers, students, children, advising the use of the life cycle perspective as a basis to give trust.

Then the panelists were questioned about that key aspects needed for the environmental footprint methodologies to be put into practice.

The panel highlighted important factors such as the need to develop some trainings for companies and non-LCA experts and guidelines translated into different languages (Mrs. Lewandowska), make it trustable for the consumers and not risk to lose trust within some years (Mr. Sonnen), create incentives on communication and make LCA tools and data accessible (Mr. Del Grosso).

Other questions raised by the audience resulted in a discussion about responsibilities for the consumers, retailers and policy makers. It was raised by Mrs. Schreiber and Mr. Van Hemelryck that some of the requirements, coming by any of the three types of stakeholders can drive the environmental performance of products or companies in the wrong direction and could be harmful. For instance, retailers are fighting to satisfy their customers and therefore they put requirements on farmers for e.g. limiting or prohibiting pesticides and herbicides use. Other requirements coming from the European Commission and/or national governments legislation also exist regarding these substances. Then farmers have to deal with so many different regulations that they do not know how to act. The panel also reflected on a market with only eco-labeled products, but as highlighted by Mr. Sonnen it seems to be a long way to go.

The panelists ended with key messages for the session. All agreed on the need for incentives for collaborations along the value chain, with other companies and with consumers. Life cycle based information appeared as the best way forward to gain trust in the market. As a scientific based method, life cycle based approached 
will give trust in the communication process. To succeed in this process, Mrs. Lewandowska once again highlighted education as one of the most powerful tools to succeed.

\section{Conclusion and Future Perspectives}

The session demonstrated that life cycle based approaches are being used among industry to identify where to act in the most efficient way when it comes to sustainability, in particular environmental sustainability. This session only gives a few perspectives on how the life cycle perspectives are being used for business management and their actions based on this information.

There was a consensus on the need to build a harmonized, scientifically based framework and methodology to produce life cycle based information one of the priority being to ensure the public trust. The European Commission works for a "Single market for green products" by developing guidelines and tools such as the PEF and OEF, aiming at harmonizing LCA practices, and Lewandowska et al. showed that eco-labelling is something that consumers pay attention to [8].

Harmonization came up and was discussed many times during the session as a mean to make a progress on the road towards sustainable businesses. From the authors' perspectives, and based on the experience of running the Swedish Life Cycle Centre, an increasing interest from government agencies to act for a harmonization at the society level has been noticed. This perspective needs to be raised to create an equal basis to operate within the market. One of the success factors for harmonization, agreed by the panelists and also identified by the Swedish Life Cycle Centre, is the important part of working together in cross-industry collaboration and not as an individual industry or organization.

The roles of ISO 14001:2015 and the PEF/OEF process on the market, and their effects at the societal level were brought up during the session. However, more discussions are required before finding a consensus on this question.

\section{References}

1. International Organization for Standardizations (ISO), ISO 14001:2015 Environmental management systems - requirements with guideline for use, ISO, 2015.

2. http://ec.europa.eu/environment/eussd/smgp/index.htm (Accessed 26.09.2017).

3. Van Hoof G, Smith C, Mcaneny J; Desylva J, Informing corporate sustainability strategies with life cycle assessment: the Procter \& Gamble footprint, LCM 2017 Conference, Luxembourg, 2017.

4. Del Grosso M, Simboli A, Cutarella N, Raggi A, Business strategies to improve the environmental performances: life cycle approaches and tools an Aptar Italia, LCM 017 Conference, Luxembourg, 2017. 
5. Sonnen M, Hallberg K, Integration of life cycle management in decision making: a monetisation approach, LCM 2017 Conference, Luxembourg, 2017.

6. Schreiber H, Humbert S, van Hemelryck S, Poivet R, Developing common rules to quantify the organisation environmental footprint in the retail sector with support of the chain-OEF approach, LCM 2017 Conference, Luxembourg, 2017.

7. Borusiak B, Jerzyk E, Kurczewski P, Lewandowska A, Sobierajewicz J, Witczak J, Dierks C, Giungato P; Suh S, How human brains interpret the environmental information on the products? A Polish case of neuro-marketing tools to assess a communication effectiveness of lite cycle based environmental labelling, LCM 2017 Conference, Luxembourg, 2017.

8. Swedish Life Cycle Centre, Life cycle based innovation-A research and innovation agenda for a leading position within industrial and societal development where the life cycle thinking and sustainability is used as a basis for innovation, CPM report no 2013:3, 2013.

Open Access This chapter is licensed under the terms of the Creative Commons Attribution 4.0 International License (http://creativecommons.org/licenses/by/4.0/), which permits use, sharing, adaptation, distribution and reproduction in any medium or format, as long as you give appropriate credit to the original author(s) and the source, provide a link to the Creative Commons license and indicate if changes were made.

The images or other third party material in this chapter are included in the chapter's Creative Commons license, unless indicated otherwise in a credit line to the material. If material is not included in the chapter's Creative Commons license and your intended use is not permitted by statutory regulation or exceeds the permitted use, you will need to obtain permission directly from the copyright holder.

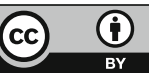

